\title{
Interactive comment on "Carbon monoxide air-pollution on sub-city scales and along arterial roads detected by the Tropospheric Monitoring Instrument” by Tobias Borsdorff et al.
}

\section{Tobias Borsdorff et al.}

t.borsdorff@sron.nl

Received and published: 6 February 2019

We would like to thank reviewer 1,2 , and 3 for the constructive comments that aided us to improve our manuscript. In this post we provide our replies to the reviewer's comments. We provide a revised version of the manuscript, in which all changes are highlighted. Revised and added text is provided in blue. In our replies to the comment we provide line numbers, page numbers and figure numbers of the old version of the manuscript.

Please also note the supplement to this comment: 
https://www.atmos-chem-phys-discuss.net/acp-2018-1185/acp-2018-1185-AC1supplement.pdf

ACPD

Interactive comment on Atmos. Chem. Phys. Discuss., https://doi.org/10.5194/acp-2018-1185, 2018.

Interactive

comment 